\title{
EFFECT OF HEMIOVARIECTOMY ON SERUM FSH AND LH LEVELS DURING THE OESTROUS CYCLE IN THE RAT
}

\author{
B. E. HOWLAND AND K. R. SKINNER \\ Department of Oral Biology, The University of Manitoba, Winnipeg, \\ Manitoba R3E OW3, Canada
}

(Received 8th August 1972)

A possible explanation for the compensatory increase in weight and function of the remaining ovary in the rat following hemiovariectomy is that gonadotrophin secretion increases due to reduced gonadal steroid levels. The observation that increased amounts of exogenous gonadotrophins are required in hypophysectomized rats to increase the ovarian weight and numbers of ovulations in hemiovariectomized rats to the levels in intact rats (Greenwald, 1968) supports this theory. Efforts to detect changes in circulating gonadotrophin levels following hemiovariectomy in the rat have been only partially successful. Edgren, Parlow, Peterson \& Jones (1965) were unable to detect changes in either FSH or LH following removal of one ovary. Benson, Sorrentino \& Evans (1969), however, reported that plasma FSH was elevated 4 days after hemiovariectomy.

Since hemiovariectomy on the day of oestrus leads to a doubling of the number of ovulations at the subsequent oestrus (Peppler \& Greenwald, 1970), changes in serum gonadotrophin levels should be evident during the oestrous cycle immediately following ovary removal. In the present study, the changes in serum FSH and LH levels during the oestrous cycle in intact and hemiovariectomized rats were compared.

Adult female rats from our own colony were placed in individual cages in a light-controlled (12 hr light/12 hr dark) and temperature-controlled $\left(74 \pm 1^{\circ} \mathrm{F}\right)$ room. Vaginal smears were examined daily to determine the stage of the oestrous cycle. Each animal was assigned to an intact or a hemiovariectomized group on the afternoon of the day of oestrus, at which time hemiovariectomy was performed. The animals were usually bled on alternate days, from the day of oestrus (before surgery) or metoestrus until the following oestrus. In a few cases, bleedings were made on 2 consecutive days. Animals failing to return to oestrus in either 4 or 5 days were eliminated from the study. At each bleeding, the rats were lightly anaesthetized with ether and approximately $1.2 \mathrm{ml}$ blood were withdrawn by heart puncture. All samples were obtained between 15.00 and 17.00 hours. Serum was stored frozen until assayed for $\mathrm{LH}$ and FSH.

Serum LH levels were determined by the $0-0$ radioimmunoassay described by Niswender, Midgley, Monroe \& Reichert (1968). The standard used was NIAMD rat-LH-RP-1. A similar double antibody radioimmunoassay dis- 
tributed by the National Institute of Arthritis and Metabolic Diseases, NIH, was used to measure FSH levels. Data for FSH are expressed in terms of NIAMD rat-FSH-RP-1. Due to limited volumes of serum, single determinations were made on most samples.

Sprague-Dawley rats were used initially and the serum was assayed for LH. Subsequently, additional rats of the Long-Evans strain were used to obtain FSH levels as well as additional LH data in cases where sufficient serum volume permitted. The LH data for both strains of rats were pooled. Differences between hormone levels for hemiovariectomized and intact rats on each day of the cycle were analysed by $t$ test.

The results are shown in Table 1 . Serum LH levels were higher in hemiovariectomized rats than in intact rats at metoestrus $(P<0 \cdot 05)$. Although the

Table 1. Serum LH and FSH levels in intact and hemiovariectomized rats

\begin{tabular}{|c|c|c|}
\hline Stage of cycle & $\begin{array}{l}L H \text { concentration } \\
(\mathrm{ng} / \mathrm{ml})\end{array}$ & $\begin{array}{c}\text { FSH concentration } \\
(\mathrm{ng} / \mathrm{ml})\end{array}$ \\
\hline Oestrus & $36 \cdot 6 \pm \quad 4 \cdot 2(36)$ & $200 \pm 10(16)$ \\
\hline $\begin{array}{l}\text { Metoestrus } \\
\text { Intact } \\
\text { Hemiovariectomized }\end{array}$ & $\begin{array}{ll}43.5 \pm & 4.9(13) \\
62.2 \pm & 4.6(13)\end{array}$ & $\begin{array}{ll}147 \pm 9 & (8) \\
214 \pm 17 & (9) * *\end{array}$ \\
\hline $\begin{array}{l}\text { Dioestrus } \uparrow \\
\text { Intact } \\
\text { Hemiovariectomized }\end{array}$ & $\begin{array}{ll}40 \cdot 3 \pm & 4 \cdot 7(17) \\
41 \cdot 4 \pm & 3 \cdot 6(14)\end{array}$ & $\begin{array}{l}128 \pm 15(10) \\
133 \pm 15 \quad(9)\end{array}$ \\
\hline $\begin{array}{l}\text { Pro-oestrus } \\
\text { Intact } \\
\text { Hemiovariectomized }\end{array}$ & $\begin{array}{l}454 \cdot 4 \pm 116 \cdot 6(17) \\
681 \cdot 3 \pm 158 \cdot 3(18)\end{array}$ & $\begin{array}{ll}239 \pm 58 & (9) \\
244 \pm 39 & (9)\end{array}$ \\
\hline $\begin{array}{l}\text { Oestrus } \\
\text { Intact } \\
\text { Hemiovariectomized }\end{array}$ & $\begin{array}{ll}27.8 \pm & 3.9(19) \\
31.5 \pm & 4.2(19)\end{array}$ & $\begin{array}{l}198 \pm 16(13) \\
246 \pm 18(14) *\end{array}$ \\
\hline
\end{tabular}

Figures given are means \pm S.E. with numbers of observations in parentheses. $\dagger$ Includes values for either day of dioestrus in rats with 5-day cycles.

$* P<0.05 .{ }^{* *} P<0.01$.

mean LH concentration at pro-oestrus appeared to be higher in hemiovariectomized rats than in intact controls, the difference was not significant. The values at pro-oestrus ranged from 35 to $2000 \mathrm{ng} / \mathrm{ml}$, indicating that some samples were obtained during the preovulatory surge of LH while others were obtained before the LH release had begun.

The levels of FSH were elevated at metoestrus in hemiovariectomized rats when compared with intact animals on the same day $(P<0.01)$. At the following oestrus, hemiovariectomized animals again demonstrated higher FSH levels than did the intact rats $(P<0.05)$. Daane \& Parlow (1971) reported that serum FSH levels rose on the afternoon of pro-oestrus and remained elevated through the afternoon of oestrus. The pro-oestrous and oestrous values determined in the present study presumably represent the initial and terminal phases of this period of elevated FSH levels.

The results suggest that removal of one ovary on the day of oestrus leads to a rise in both LH and FSH on the following day. The elevated FSH levels at 
metoestrus in hemiovariectomized rats could be responsible for the increased follicular development that has been noted during the remainder of the cycle (Peppler \& Greenwald, 1970). The elevated FSH levels in hemiovariectomized rats at the next oestrus may indicate a more prolonged periovulatory release of FSH. A greater total amount of FSH released at this time could be the factor which determines the number of follicles which will develop and ovulate at the following oestrus.

The authors are grateful to Dr G. D. Niswender, Dr L. E. Reichert, Jr and the National Institute of Arthritis and Metabolic Diseases, Rat Pituitary Hormone Program for supplying the radioimmunoassay materials. This study was supported by grant MA-4454 from the Medical Research Council of Canada and was conducted while one of us (K.R.S.) held an MRC summer scholarship.

\section{REFERENGES}

Benson, B., Sorrentino, S. \& Evans, J. S. (1969) Increase in serum FSH following unilateral ovariectomy in the rat. Endocrinology, 84, 369.

DaAne, T. A. \& Parlow, A. F. (1971) Periovulatory patterns of rat serum follicle stimulating hormone and luteinizing hormone during the normal estrous cycle: effects of pentobarbital. Endocrinology, 88, 653.

Edgren, R. A., Parlow, A. F., Peterson, D. L. \& Jones, R. C. (1965) On the mechanisms of ovarian hypertrophy following hemicastration in rats. Endocrinology, 76, 97.

GREenwald, G. S. (1968) Influence of one or two ovaries on ovulation and ovarian weight in the hypophysectomized rat. Endocrinology, 82, 591 .

Niswender, G. D., Mmgley, A. R., JR, Monroe, S. E. \& Reichert, L. E., JR (1968) Radioimmunoassay for rat luteinizing hormone with antiovine LH serum and ovine LH- ${ }^{131}$ I. Proc. Soc. exp. Biol. Med. 128, 807.

Peppler, R. D. \& Greenwald, G. S. (1970) Effects of unilateral ovariectomy on ovulation and cycle length and 4- and 5-day cycling rats. Am. F. Anat. 127, 1. 